Indonesian Journal of EFL and Linguistics

Vol. 2 No. 1, 2017

eISSN: 2503-4197, pISSN: 2527-5070

www. indonesian-efl-journal.org

\title{
Utilizing Video for Technology Integration Support in Indonesian EFL Classroom: Usages and Obstacles
}

\author{
Muhamad Nova \\ Postgraduate Program of English Education, Universitas Pendidikan Indonesia \\ e-mail:mohnova@student.upi.edu
}

\begin{abstract}
:
The use of video as a solution in supporting technology integration in EFL teaching and learning process in Indonesia still faces some obstacles in its utilization. Viewing from this issue, this study explored Indonesian EFL teacher's perceptions on the usages and obstacles in utilizing video in teaching and learning process. Conducting a survey research by distributing questionnaires purposively to $30 \mathrm{EFL}$ teachers, 22 females and 8 males, the results revealed that the Indonesian EFL teachers found that video is very beneficial in teaching and learning process, especially in delivering the learning material, building students' background knowledge, bringing real-life language context, providing visual and audio input, and serving varieties of language expressions. It also gives positives impacts to students' learning attitudes, including their interest, motivation, and learning styles. Even though it brings beneficiary effects, many Indonesian EFL teachers also mentioned five obstacles faced in using video in their classroom: limitation of facilities at school, lack of technical support at school, difficulties in finding suitable video, lack of skill in editing video, and less focus students on learning. Reflecting up from these results, it is suggested for EFL teachers to use video in improving the teaching and learning process in the classroom. It is also recommended for the EFL teachers to attend teacher professional development program to enrich their competence and skill in using video in teaching and learning process. Moreover, school principals' are recommended to support the school facilities to promote technology integration at school.
\end{abstract}

Keywords: EFL classroom; technology integration; video; video obstacles; video usages

Indonesian Journal of EFL and Linguistics, Vol. 2 (1), 2017 


\section{INTRODUCTION}

In implementing the newest curriculum, Indonesian educational system faced several problems in achieving its goal to make a better educational process in the society. Particularly, one obstacle which still gains many attentions from the educators is technology integration. Integrating technology-based media still becomes a problem by some English teachers since they are unable to serve interesting technology-based media in classroom and prefer to deliver the learning material in a traditional way. In fact, in the newest curriculum in Indonesia, it is mentioned that the technology should be integrated in teaching and learning process to improve the efficiency and effectiveness of teaching and learning process. Therefore, the English teachers are demanded to provide technology integration in teaching and learning activities to increase the efficiency and effectiveness of teaching and learning process.

Video as one means in language teaching and learning may become a solution in helping the English teacher in providing technology integration in teaching and learning process. It provides original and authentic input for students as they are produced originally for native speakers (Bajrami \& Ismaili, 2016). Moreover, it also provides a real language expression with cultural information of target language learned by the students (Shahani \& Tahriri, 2015). It enhances the language teaching and learning activities and the students generally felt that technology is useful for learning ESL. Their usage is more for recreation than for learning ESL (Thang, et al., 2016).

Furthermore, it also provides both appropriate visual and audio input which can help the students acquire new knowledge (Bal-Gezegin, 2014). Thus, the students can observe specific facial expressions and gestures (Safarali \& Hamidi, 2012), and emotional attitudes (Bajrami \& Ismaili, 2016) shown by the speakers in the video.

Viewing the utilization of video can solve both problems in providing technology integration and serving interesting media in English teaching and learning activities, this study explored Indonesian EFL teacher's perceptions on the usages and obstacles in utilizing video in teaching and learning process. Related to these research objectives, the research questions proposed in this study were:

1. What are the usages found by Indonesian EFL teachers in utilizing video in teaching and learning activities in classroom?

2. What are the obstacles found by Indonesian EFL teachers in utilizing video in teaching and learning activities in classroom?

As the result of this study revealed, other EFL teachers can reflect on their own teaching and raise their awareness on the benefits of having video to support technology integration and serve interesting media in English teaching and learning activities. Besides, from the obstacles found, the Indonesian EFL teachers may find the solution to overcome the problems in utilizing video in teaching and learning activities and share the problems with school administrative and principals. 


\section{LITERATURE REVIEW}

\subsection{Technology Integration in English Teaching and Learning Process}

The utilization of technology in language teaching and learning process had been proven to bring positive impacts for many aspects by several researchers. It enhances the language teaching and learning activities (Mahmood, Bokhari, \& Naqvi, 2011) and improves the effectiveness of teaching and learning instruction (Lakshmi, 2012; Wu, Pan, \& Yuan, 2016; Munir, 2016; Rakhmawati, 2016). It also fosters students' learning attitudes, including their enthusiasm (Isisag, 2012), interest (Al-Mohammadi \& Derbel, 2014; Alresheed, Leask, \& Raiker, 2015), and motivation (Al-Mohammadi \& Derbel, 2014; Altun, 2015; Anikina, Sobinova, \& Petrova, 2015) and also supports learning style diversity (Ezza \& Bakry, 2014) for all students in the classroom. Furthermore, the existence of technology also helps the teacher in improving the teachers' teaching performance, including problem solving, classroom interaction, and teaching and learning activity design (Al-Maagbeh, 2015).

Although it had been proven that the existence of technology integration gives positive impacts for English teaching and learning process, the fact that EFL teachers also faced some obstacles in integrating technology in classroom also have been investigated.

A study conducted by Tanveer (2011) who investigated the perceptions from both EFL students and teachers in Oman found that the major challenges in integrating technology in classroom are less technology support, lack of confidence, lack of experience of teachers and students with technology, limitation of time in preparing their instructions for electronic transmission of knowledge, and lack of e-learning resources.

Another study conducted by Hu and McGrath (2012) in integrating ICT into college English also found several obstacles in implementing technology integration. They carried out that insufficient ICT facilities, teachers' limited ICT skills and pedagogic expertise, lack of effective communication networks, and inadequate technical support and ICT-related training hindered the ICT implementation in China.

Laabidi \& Laabidi (2016) found that Moroccan university English language teachers face multiple barriers such as large classes, lack of computers, lack of Internet and insufficient technical support that prevent them from using ICT in their teaching practices. This findings supported by Chouit, et al. (2017), they found that the barriers that limited professors' use of computer technology for pedagogical objectives were lack of basis infrastructure, lack of equipments and materials, lack of teachers' computer skills, and lack of appropriate computer training, lack of time, and lack of administrative support.

Raman and Mohamed (2013) also conducted a similar study in investigating the issues in integrating ICT in teaching English in Malaysian secondary school. He found several issues in technology integration in Malaysia, including lack of access to technology, lack of time, lack of technical support, lack of professional 
development on how to integrate technology, lack of school funding, and lack of support from administrators.

Similar study was also conducted by Hedayati and Marandi (2014) in Iran. They explored the difficulties in implementing computer-assisted language learning in Iranian EFL classroom. Their study revealed that limited availability or lack of digital technologies and having negative attitudes of being fear of additional workload become two main major problems in implementing computer-assisted language learning. Then, they also found that the students' insufficient digital literacy, book-based instruction dependency, and limited access of technology outside of classroom were also considered to be the factors influencing the consideration in implementing computer-assisted language learning in teaching and learning process.

Moreover, Alresheed and Leask's study (2015) in exploring the factors affecting Computer-Assisted Language Learning in Saudi Arabia EFL classrooms also carried out some obstacles in having technology integration in teaching and learning process. Their findings showed that some negative factors in implementing CALL were negative attitudes from teachers, fears of wrongful usage on technology tools, lack of technological engagement in general, lack of pedagogical knowledge and sufficient training in both teaching English and ICT, and lack of computers and software.

In line with the statement above, Laabidi (2016) claims that there are significant differences between professors' integration of the new technologies based on age. In fact, young teachers tend to make more use of ICT for instructional purposes than older professors. Therefore, it is possible to conclude that age might have some impacts on professors' decision to incorporate modern technologies in their classrooms.

Thus, the integration of technology may give beneficial effect for English teaching and learning process. However, the utilization of technology also needs to be considered in some aspects since there are some problems occurring in integrating technology in classroom, including less technology support for both facilities and technical support, teacher's problems, such as lack of confidence, lack of skill, lack of training, lack of pedagogical knowledge, lack of time preparation, and negative attitudes, and also students' lack of technology literacy and access.

\subsection{Video in English Teaching and Learning Process}

The existence of video in language teaching and learning process is not a new matter. Video has become as a teaching resource in language teaching and learning process since 1970s (Bal-Gezegin, 2014) and still being used nowadays in many English classroom. It has been categorized as an interesting media (Bajrami \& Ismaili, 2016; Shahani \& Tahriri, 2015) which creates a meaningful learning for students (Bajrami \& Ismaili, 2016; Marefat \& Hassanzadeh, 2014) since it provides both appropriate visual and audio input for the students (Bal-Gezegin, 2014; Gowhary, et al., 2014; Marefat \& Hassanzadeh, 2014; Shahani \& Tahriri, 2015). Thus, the students can observe specific facial expressions (Bal-Gezegin, 2014; 
Safarali \& Hamidi, 2012), gestures (Safarali \& Hadi Hamidi, 2012), and emotional attitudes (Bajrami \& Ismaili, 2016) shown by the speakers in the video.

Moreover, the application of video in classroom can also improve the quality of language teaching and learning process. It serves contextual input on where a specific language expression is spoken in certain situation (Gowhary, et al., 2014; Shahani \& Tahriri, 2015). It also shows the real-life language use as its authenticity (Bajrami \& Ismaili, 2016; Bal-Gezegin, 2014; Shahani \& Tahriri, 2015; Soong, 2012) and the culture of target language (Bajrami \& Ismaili, 2016; Park \& Jung, 2016; Shahani \& Tahriri, 2015).

In addition, previous scholars also had proven the advantages of using video as one media in English language teaching and learning process, including students' learning attitudes, students' language enrichment, and comparison between audio and video efficiency.

A study on investigating the effect of video on students' learning attitudes has been investigated by Ockert (2015). He had conducted a study investigating the correlation of recording and viewing video activities with Japanese EFL students' affective variables. The result showed strong correlations between video activities, international situation, and motivation, with students' communicative competence which can be identified that the Japanese EFL students are motivated to speak in English since their recording will be viewed by the foreign students abroad. Moreover, the addition of video recording in English teaching and learning activities can boost these students' confidence to speak in English. By using video, it has been shown that Japanese EFL students' motivation and confidence are improved.

Park and Jung (2016) also established another similar study on investigating the effect of video on students' learning attitudes. They had employed an action research to evaluate the effectiveness of a video-based curriculum in motivating Korean EFL secondary school students in learning English. They applied 8 weeks English program which provided video clips in the classroom including TED talk replays, sitcoms, TV news reports and movies as its main study material. The results revealed that the Korean EFL students became more motivated and perceived a positive attitude toward English language and culture. Then, followed with a set of competitive group activities, this watching of video agenda positively influenced these students participation in teaching and learning process. Thus, this study has shown that the use of video clips is effective in improving students' motivation and participation.

Regarding to students' language enrichment, Kabooha \& Elyas (2015) investigated the impact of integrating YouTube video clips during reading activities on the development of vocabulary comprehension and recognition of Saudi EFL students. It was carried out that the integration of YouTube videos provided significant effects on the students' vocabulary acquisition. The findings of their study also indicated that positive attitudes among Saudi EFL students towards the use of YouTube videos in acquisitioning new vocabularies. Besides, well selected video materials 
provided in this study also could enhance Saudi EFL students` language learning process their motivation in learning English.

In the same year, Shahani \& Tahriri (2015) carried out a study on finding the effect of silent and freeze frame viewing techniques of video materials on the intermediate Iranian EFL students' listening comprehension. The findings of this study carried out that the video's audiovisual stimuli are interesting and provides a real language expression completed with target language cultural information. Moreover, it also provided different aspects of speech like stress, tone, and/or even facial expressions or body language which can improve Iranian EFL learners' listening ability significantly.

Furthermore, Bal-Gezegin (2014) conducted a study to compare the efficiency of video and audio in teaching Turkish EFL students on English vocabulary learning. It was found that the use of video can enhance learning process since it provides specific fixed expression. The students in video group enjoy the video and find it motivating them in learning English. In spite of, the students in audio group are not as motivated, willing, and enthusiastic as the students in video group. They found the difficulties in understanding the audio such as the speakers spoke too fast or the accent was hard to grasp. Thus, the use of video might lead better vocabulary learning in language classrooms when compared to the use of audio material only.

Therefore, reflecting up from these related studies, the utilization of video in English teaching and learning process can give positive effects for fostering students' positive learning attitudes, including their motivation, confidence, interest, and participation, and improving students' language enrichment, especially in acquiring new vocabularies.

\section{RESEARCH METHODOLOGY}

This study was conducted using a survey research design. Survey research was selected in purpose of collecting the data from sample representing Indonesian EFL teachers. In this study, 30 Indonesian EFL teachers coming from different educational institutions were purposively selected and contacted to participate in the study. These selected EFL teachers are the teachers who have been teaching English using video as the media provided in teaching and learning process in classroom. The total was consisted of 22 female teachers (FT) and 8 male teachers (MT). The data were collected through questionnaire which was designed to answer the research questions related to the objectives of the study. The questionnaire consisted of two open-ended questions which covers the usages and the obstacles in utilizing video in teaching and learning process in classroom. These questions were constructed in respondent's first language to make the respondents answer more accurately. Therefore, the questionnaire questions were constructed in Bahasa Indonesia since this study investigated Indonesian EFL teachers. The questionnaires were distributed and the filled-in questionnaires were submitted back. Then, responses written in filled-in questionnaire, which were the Indonesian EFL teachers' perception on the usages and obstacles in utilizing video in teaching and learning process, were analyzed descriptively. After analyzing the data, the 
interpretation of the data were created and then the interpretation of the result was discussed with related theories and previous researches.

\section{FINDINGS}

\subsection{Usages of Video Utilization in Indonesian EFL Classroom}

From Indonesian EFL teachers' responses, it was revealed that the utilization of video in English teaching and learning process was served in different purposes in teaching and learning activities. They found that the existence of video as their teaching media is very beneficial, especially for improving the teaching and learning activities and fostering positive learning attitudes from the students.

Some of these Indonesian EFL teachers mentioned that they used the video as a media for explaining the learning material easier (FT.6, FT.9, FT.11, FT.12, and MT.7).

- "The students can understand the learning material easier, and also in delivering the learning context won't be difficult, such as describing something, the students can see the video or picture and they can understand what is being discussed in the classroom." (FT.11)

- "Video is used to show the learning content which cannot be imagined by students." (MT.7)

Some others also mentioned that the video is placed at the beginning of the lesson since it can build students' background knowledge (FT. 1, MT.5, and MT.6).

- "Video is used to makes the students more focus on learning situation. It also raises their imagination and it is used in building their knowledge in the beginning of the lesson." (MT.5)

- "I used the video as the brainstorming in introductory of the lesson." (MT.6)

On the other hand, other Indonesian EFL teachers also mentioned that they have chosen video as the means in teaching and learning activities since it brings real situation of language in its authenticity (FT.1, FT.4, FT.12, FT.13, FT.20, and FT.21).

- "Video is used to show real situation in English environment." (FT.1)

- "I use video and it helps the students by providing authentic learning material, such as news video." (FT.12)

The others also stated that video provides visual and audio input for the students (FT.5, FT.14, FT.16, FT.17, MT.1, and MT.2).

- "Video makes the students practice their audiovisual." (FT.5)

- "Video makes the students have a better understanding on learning since video can give visual and auditory input toward the concept learnt." (MT.2)

Moreover, some of them also mentioned that it serves the language expression used (FT.8, FT.15, FT.19, and FT.22). 
- "Video is provided to learn language expression and makes the students understand and know what language is being expressed." (FT.8)

- "Video gives a case study related to the learning topic, such as language expressions or dialogues." (FT.22)

Many Indonesian EFL teachers also found that video could gain students' interest in learning English (FT.1, FT.2, FT.3, FT.10, MT.1, MT.3, MT.4, and MT.8).

- "Video helps the students to be easier in understanding the topic lesson which is previously or later will be presented in the classroom. It makes the learning environment become more interesting by using video." (MT.4)

- "Video is very interesting. It is not boring. The students are waiting for it in the classroom. They are excited and happy." (MT.8)

Other Indonesian EFL teachers also mentioned that video can foster students' motivation in learning English (FT.7 and FT.22).

- "Video raises students' motivation in learning." (FT.7)

- "Video also motivates the students to like English, such as an artist continues his or her study abroad, or tutorial video in doing something using English." (FT.22)

Furthermore, some of these teachers also revealed that video can support students' learning style in classroom (FT.17 and MT.3).

- "The use of video makes the students easier in learning and stimulates them in learning, particularly for visual and auditory learner." (FT.17)

- "Video increases students' interest in learning and it can be adapted by any students' learning styles.” (MT.3)

\subsection{Obstacles of Video Utilization in Indonesian EFL Classroom}

From Indonesian EFL teachers' responses, there are five obstacles in utilizing video in Indonesian EFL teaching and learning process: limitation of facilities at school, lack of technical support at school, difficulties in finding suitable video, lack of skill in editing video, and less focus students on learning.

Mostly, Indonesian EFL teachers mentioned that the school facilities are limited and it becomes their major obstacles in utilizing video in their classroom (FT.1, FT.5, FT.6, FT.7, FT.8, FT.9, FT.10, FT.11, FT.13, FT.14, FT.16, FT.18, FT.20, MT.1, MT.3, MT.4, MT.6, and MT.7).

- "Lack of school facilities, such as not having electricity in some classrooms and also the limitation of projector at school." (FT.16)

- "The school facilities equipment is limited, such as LCD, projector, and loudspeaker, and also the internet connection. No internet connection at my school." (MT.3) 
Besides, the Indonesian EFL teachers also mentioned lack of technical support in dealing with the utilities. The major problem with lack of technical support is the electricity at their school went off (FT.2, FT.9, FT.15, and FT.17).

- "There are some technical obstacles and limitation of electricity at my school. Sometimes in the middle of learning process the electricity is off." (FT.2)

- "Sometimes, suddenly the electricity is off. I cannot use the video." (FT.15)

Another case also happened when the utilities are broken, such as cables, LCD, or projector (FT.3, MT.1, and MT.5).

- "We have broken facilities, such as broken cable. So it is useless." (FT.3)

- "The implementation of any ICT media is limited in certain schedule. Then, the technical problem such as black out, the computer stuck, projector problem, broken cable, also happen sometimes. The school needs higher budget to facilitate the ICT media in classroom." (MT.1)

Besides, these Indonesian EFL teachers also stated that they felt difficult in finding and selecting suitable learning material to be served in classroom (FT.2, FT.4, FT.6, FT.12, FT.13, FT.17, FT.21, MT.2, MT.6, and MT.8).

- "Sometimes it is difficult to find appropriate and accurate sources which fits to the learning topic." (FT.4)

- "The availability and material sources become one problem that I have. It is difficult to find suitable source which suits the students' level." (FT.6)

Moreover, they also mentioned that they had lack of skill in editing the video (FT.3, FT.13, and MT.2).

- "Finding appropriate video for the learning material is difficult, such as looking for its sources, editing, cutting, and proposing into appropriate learning material, then sometimes recording own videos is also difficult." (FT.13)

- "Sometimes finding a good video is too long and needs time and skill to edit it to take the specific part of the video related to the learning material." (MT.2)

Another obstacle mentioned by these Indonesian EFL teachers is coming from the students. They stated that the students have less focus into learning process and more focus on watching the video shown in the classroom (FT.8, MT.5, and MT.8).

- "Well, some of the students cannot understand the learning material in the video. So it needs repetition sometimes." (FT.8)

- "Sometimes the students have less focus in learning process. They only focus on the video shown but do not catch the learning objective or any lesson served in the video." (MT.8) 


\section{DISCUSSION}

In this study, Indonesian EFL teachers' perceptions on the usages and obstacles in utilizing video in teaching and learning process were investigated. From the findings revealed, the benefits of video utilization have been recognized by these Indonesian EFL teachers. They mentioned that the utilization of video in classroom makes them easier in delivering the learning material since it can build students' background knowledge, bring real-life language context, provide visual and audio input, and serve language expressions expressed by the speakers. It is in line with the literature discussed above that the existence of video in English teaching and learning process can bring audiovisual input for the students (Bal-Gezegin, 2014; Gowhary, et al., 2014; Marefat \& Hassanzadeh, 2014; Shahani \& Tahriri, 2015) which can help the students in acquiring new knowledge (Bal-Gezegin, 2014). Moreover, it is also in line with Shahani and Tahriri (2015) who agreed that video gives the students the real-life example of language expressions used by the native one and thus it can increase students and teachers' awareness about English language features videos. Then, the originality and authenticity input given from video utilization for the students is in line with Bajrami and Ismaili (2016). They also discussed that videos can be used in any phase of teaching and learning process in classroom, such as presenting content, initiating discussion, providing illustration, self-study or evaluation situations, and in this study Indonesian EFL teachers found that video is very useful to be placed at the beginning of the lesson and builds students' background knowledge on related topic being discussed in the classroom.

Another findings discovered on this study on the usages of video utilization in EFL learning revealed that video also gives positives impacts to students' learning attitudes, including their interest, motivation, and learning styles. The existence of audiovisual can gain students' interest (Shahani \& Tahriri, 2015), especially for those whose learning styles are visual and auditory. Thus, video can support these visual and auditory students to catch the learning better. Moreover, the visual aids given in video, such as the facial expression and gestures, increase the enjoyment in learning and may foster students' motivation (Bal-Gezegin, 2014).

Though, the Indonesian EFL teachers did not recognize the existence of target language culture exist in the video. The appearance of culture learning can raise students' cultural diversity awareness (Park \& Jung, 2016) and the visual aids provided in video can serve the target language culture as additional information in learning the target language where the students can observe how the target language people behave in their culture (Bajrami \& Ismaili, 2016). Thus, the utilization of video in classroom may create a meaningful learning for the students (Bajrami \& Ismaili, 2016).

Even though the application of video brings positive effects on teaching and learning activities, many Indonesian EFL teachers also have found several obstacles in using video in their classroom. In this study, it is revealed that the major obstacles found by Indonesian EFL teachers are limitation of facilities at school, lack of technical support at school, difficulties in finding suitable video, lack of skill in editing video, and less focus students on learning. The less school support on facilities and 
technical support have also become a major problem in integrating technology in EFL classroom in other countries, such as in Oman (Tanveer, 2011), China (Hu \& Mcgrath, 2012), Malaysia (Raman \& Mohamed, 2013), Iran (Hedayati \& Marandi, 2014) and Saudi Arabia (Alresheed \& Leask, 2015). Raman and Mohamed (2013) found that the lack of school funding may become one factor which makes the school have not provided the school facilities. The high cost of technology utilities needs a good management in managing the school funding. Moreover, the difficulties in finding learning sources are also categorized as one major problem haunting the integration of technology (Tanveer, 2011), especially for EFL teachers who have limited time in preparing the media itself (Raman \& Mohamed, 2013; Tanveer, 2011). Meanwhile, the lack of skill existed is the result of having insufficient training for EFL teachers toward the use of technology in teaching and learning process (Alresheed \& Leask, 2015; Hu \& Mcgrath, 2012). Therefore, school support is needed to enrich teachers' knowledge and ability in utilizing technology in classroom. Furthermore, the effect of having less focus students on learning becomes a new findings related to the existence of technology-based media as a learning distraction in learning.

In addition, to apply ICT in teaching and learning environment, the availability of recourses is one of the key factors, including the resources of utilities, pedagogies, and learning sources (Gebremedhin \& Fenta, 2015). Therefore, to support the technology integration program, school plays a big role in maintaining the problem occurs in technology integration, finding the appropriate solution to overcome the problem, and providing the resources to support the integration of technology in teaching and learning process.

\section{CONCLUSION}

From the results revealed, it can be concluded that the Indonesian EFL teachers found that the utilization of video is very beneficial in teaching and learning process. They feel the utilization of video in classroom makes them easier in delivering the learning material since it can build students' background knowledge, bring real-life language context, provide visual and audio input, and serve language expressions expressed by the speakers. It also gives positives impacts to students' learning attitudes, including their interest, motivation, and learning styles. Even though it brings beneficiary effects, many Indonesian EFL teachers also faced five obstacles in using video in their classroom, including the limitation of facilities at school, the lack of technical support at school, the difficulties in finding suitable video, the lack of skill in editing video, and the less focus students on learning. Reflecting from the result revealed, it is suggested for EFL teachers to use video in improving the teaching and learning process in the classroom. It is also recommended for the EFL teachers to attend teacher professional development program and training to enrich their competence and skill in using video in teaching and learning process. Moreover, school principals' are recommended to support the school facilities to promote technology integration at school. In addition, this study was limited to small sample of Indonesian EFL teachers which mostly come from city. Different kind of sample may influence the result of its video utilization obstacles, especially in rural

Indonesian Journal of EFL and Linguistics, Vol. 2 (1), 2017 
area. Thus, further research is suggested to take a wider sample to gain additional factors which become the obstacles in utilizing video in EFL classroom.

\section{Acknowledgement}

The research was funded by Indonesia Endowment Fund for Education Scholarship (LPDP), Ministry of Finance, Republic of Indonesia (Grant No. 20160611087314).

\section{REFERENCES}

Al-Maagbeh, I. F. (2015). The effectiveness of devising an ICT program in developing efficiency classroom management of EFL teachers' in rural basic schools at Al-Karak directorate-Jordan. Research on Humanities and Social Sciences, 5(10), pp. 120-137. Retrieved from https://www.researchgate.net/publication/282283492

Al-Mohammadi, S. \& Derbel, E. (2014). The effects of embedding information technologies within ELT on EFL learners' motivation and interest. International Journal of Applied Linguistics \& English Literature, 3(1), pp. 181-186. DOI:10.7575/aiac.ijalel.v.3n.1p.181

Alresheed, S. \& Leask, M. (2015). Factors affecting computer-assisted language learning in Saudi Arabia classrooms. Paper presented at the 9th International Technology, Education and Development (INTED) 2015 Conference, pp. 1-10. Retrieved from https://www.researchgate.net/publication/273445264

Alresheed, S., Leask, M., \& Raiker, A. (2015). Integrating computer-assisted language learning in Saudi schools: A change model. The Turkish Online Journal of Educational Technology, 14(1), pp. 69-77. Retrieved from https://www.researchgate.net/publication/282769450

Altun, M. (2015). The integration of technology into foreign language teaching. International Journal on New Trends in Education and Their Implications, 6(1), $\quad$ pp. 22-27. 2 Retrieved from http://www.ijonte.org/FileUpload/ks63207/File/03a.altun.pdf

Anikina, Z., Sobinova, L., \& Petrova, G. (2015). Integrating telecollaboration into EFL classroom: Theoretical and practical implications. Procedia - Social and Behavioral Sciences, 206(2015), pp. 156-161. DOI:10.1016/j.sbspro.2015.10.045

Bajrami, L. \& Ismaili, M. (2016). The role of video materials in EFL classrooms. Procedia - Social and Behavioral Sciences, 232(2016), pp. 502-506. DOI:10.1016/j.sbspro.2016.10.068

Bal-Gezegin, B. (2014). An investigation of using video vs. audio for teaching vocabulary. Procedia - Social and Behavioral Sciences, 143(2014), pp. 450457. DOI:10.1016/j.sbspro.2014.07.516

Chouit, D., Nfissi, A., Laabidi, H. (2017). Exploring the Correlation between Professors' Use of ICT in Teaching and the Levels of Institutional Support. JELTL (Journal of English Language Teaching and Linguistics), 2(1), 2017. doi: http://dx.doi.org/10.21462/jeltl.v2i1.39 
Ezza, E. S. Y. \& Bakry, S. A. (2014). Technology-enhanced instruction in a Saudi EFL classroom. Arab World English Journal, Special Issue on CALL (1), pp. 55-66. Retrieved from https://www.researchgate.net/publication/272415469

Gebremedhin, M. A. \& Fenta, A. A. (2015). Assessing teachers' perception on integrating ICT in teaching learning process: The case of Adwa college. Journal of Education and Practice, 6(4), pp. 114-124. Retrieved from https://www.researchgate.net/publication/278303385

Gowhary, H., Pourhalashi, Z., Jamalinesari, A., \& Azizifar, A. (2014). Investigating the effect of video captioning on Iranian EFL learners' listening comprehension. Procedia - Social and Behavioral Sciences, 192(2015), pp. 205-212. DOI:10.1016/j.sbspro.2015.06.029

Hedayati, H. F. \& Marandi, S. (2014). Iranian EFL teachers' perceptions of the difficulties of implementing CALL. ReCALL, 26(3), pp. 298-314. Retrieved from https://www.researchgate.net/publication/251880750

$\mathrm{Hu}, \mathrm{Z}$. \& McGrath, I. (2012). Integrating ICT into college English: An implementation study of a national reform. Education and Information Technologies, 17(2), pp. 147-165. DOI:10.1007/s10639-011-9153-0

Isisag, K. U. (2012). The positive effects of integrating ICT in foreign language teaching. Paper at the International Conference of ICT for Language learning 5th edition, pp. 1-5. Retrieved from http://conference.pixelonline.net/ICT4LL2012/common/download/Paper_pdf/235-IBT107-FP-IsisagICT2012.pdf

Kabooha, R. \& Elyas, T. (2015). The impacts of using YouTube videos on learning vocabulary in Saudi EFL classrooms. Paper presented at the ICERI 2015 Conference, pp. 3525-3531. Retrieved from https://www.researchgate.net/publication/283153582

Laabidi, Hicham. (2016). The Effect of Age on English Professors' Integration of the New Technologies in Teaching. IJELTAL (Indonesian Journal of English Language Teaching and Applied Linguistics), 1(1), 2016

Laabidi, Youssouf \& Laabidi, Hicham. (2016). Barriers Affecting Successful Integration of ICT in Moroccan Universities. JELTL (Journal of English Language Teaching and Linguistics), 1(3), 2016

Lakshmi, B. S. (2012). Reflective Practice through Video Recording and Journal Writing-A Case Study. 3L: Language, Linguistics, Literature ${ }^{\circledR}$, Vol 18, No 4 (2012)

Mahmood, A., Bokhari, N. H., \& Naqvi, F. (2011). Effects of use of ICT: Students' perception at higher education level. Elixir Social Studies, 38(2011), pp. 42184221. Retrieved from https://www.researchgate.net/publication/273756400

Marefat, F. \& Hassanzadeh, M. (2014). Vodcast: A breakthrough in developing incidental vocabulary learning? Iranian Journal of Applied Linguistics, 17(2), pp. 27-58. Retrieved from https://www.researchgate.net/publication/283346575

Munir, Fathul. (2016). The Effectiveness of Teaching Vocabulary by Using Cartoon Film toward Vocabulary Mastery of EFL Students. JELTL (Journal of English Language Teaching and Linguistics), 1(1), 2016 
Ockert, D. (2015). A correlation analysis of tech-based English activities and Japanese elementary student affective variables. Journal of Second Language Teaching and Research, 4(1), pp. 1-12. Retrieved from https://www.researchgate.net/publication/283615290

Park, Y. \& Jung, E. (2016). Exploring the use of video-clips for motivation building in a secondary school EFL setting. English Language Teaching, 9(10), pp. 8189. DOI:10.5539/elt.v9n10p81

Rakhmawati, S.S. (2016). The Role of Moving Images in the Conference Interpreting Classroom. Indonesian Journal of Applied Linguistics, Vol 5, No 2 (2016)

Raman, A. \& Mohamed, A. H. (2013). Issues of ICT usage among Malaysian secondary school English teachers. English Language Teaching, 6(9), pp. 7482. DOI:10.5539/elt.v6n9p74

Safarali, S. K. \& Hamidi, H. (2012). The impact of videos presenting speakers' gestures and facial clues on Iranian EFL learners' listening comprehension. International Journal of Applied Linguistics \& English Literature, 1(6), pp. 106-114. DOI:10.7575/ijalel.v.1n.6p.106

Shahani, S. \& Tahriri, A. (2015). The impact of silent and freeze-frame viewing techniques of video materials on the intermediate EFL learners' listening comprehension. Sage Open, 5(2), pp. 1-8. DOI:10.1177/2158244015585999

Soong, D. (2012). Using documentary films in oral interpretation class: What is the appropriate length? International Journal of Applied Linguistics \& English Literature, 1(6), pp. 131-141. DOI:10.7575/ijalel.v.1n.6p.131

Tanveer, M. (2011). Integrating E-learning in classroom-based language teaching: Perceptions, challenges and strategies. Paper presented at the $4^{\text {th }}$ International Conference "ICT for Language Learning, pp. 1-6. Retrieved from http://conference.pixel-

online.net/ICT4LL2011/common/download/Paper_pdf/IEC141-252-FP-

Tanveer-ICT4LL2011.pdf

Thang, S.M., et al. (2016). ICT Tools Patterns of Use among Malaysian ESL Undergraduates. GEMA Online ${ }^{\circledR}$ Journal of Language Studies, Vol 16, No 1 (2016)

Wu, Y. C. J., Pan, C. I., \& Yuan, C. H. (2016). Attitudes towards the use of information and communication technology in management education. Behavior \& Information Technology, 1(1), pp.1-12. DOI:10.1080/0144929X.2016.1212928 